\title{
МАКРОФИТОБЕНТОС В БОЛЬШИХ ЭКОСИСТЕМАХ ЮЖНЫХ МОРЕЙ РОССИИ
}

\author{
(C) 2020 г. О. В. Степаньян* \\ Федеральный исследовательский центр Южный научный центр РАН, Ростов-на-Дону, Россия \\ *e-mail: step@ssc-ras.ru \\ Поступила в редакцию 29.12.2018 г. \\ После доработки 02.10.2019 г. \\ Принята к публикации 28.11.2019 г.
}

\begin{abstract}
В рамках концепции Больших морских экосистем дается оценка состояния и динамики изменений качественных и количественных показателей макрофитобентоса (морские макроводоросли и травы) южных морей России. Показано, что перестройки видового состава и пространственного распределения макрофитобентоса морских экосистем (Азовское, Каспийское моря) связаны с колебаниями солености и уровня моря. Для Северного Каспия (российский сектор) с начала 2000-х годов отмечается увеличение доли сапробного комплекса зеленых и красных водорослей, расширение зоны обитания Zostera noltii, что обусловлено изменениями солености и уровня воды в водоеме. Наибольшая деструкция фитосообществ в Черном море наблюдается в морских эстуариях - портовых акваториях, в том числе в Новороссийской бухте. Наиболее устойчивыми к действию нефтепродуктов являются бурые водоросли (цистозировые), менее - зеленые (ульвовые) и красные (церамиевые). Построены математические модели отклика водной и прибрежно-водной растительности Северного Каспия на изменение уровня и солености воды, которые адекватно отражают происходящие природные процессы и позволяют прогнозировать влияние климата и антропогенной нагрузки (хозяйственной деятельности) на водные биоресурсы. Указывается на необходимость оценки экосистемных услуг макрофитобентоса для экономики России.
\end{abstract}

Ключевые слова: макрофитобентос, морские макроводоросли, морские травы, Большие морские экосистемы, изменения климата, загрязнение, промысел

DOI: $10.31857 / \mathrm{S} 2587556620020132$

\section{ВВЕДЕНИЕ}

Морские макрофиты (макроводоросли и травы) являются важным компонентом прибрежных экосистем. Их видовой состав, пространственное и вертикальное распределение, особенности биологии, экологии и физиологии отдельных видов определяются, прежде всего, климатическими (океанографическими) факторами и уровнем загрязнения морской среды. Донные беспозвоночные и водоросли - хороший биоиндикатор климатических изменений в Мировом океане и внутриконтинентальных морях [16, 47]. Наиболее информативными параметрами при оценке изменений климата являются видовое разнообразие, биомасса и пространственное распределение водорослей. В южных морях России макроводоросли и морские травы образуют до $60 \%$ первичной продукции [3]. Часть видов (водоросли - Cystoseira, Phyllophora, морские травы Zostera) являются важными промысловыми объектами.

Используя подходы, разработанные в концепции Больших морских экосистем (БМЭ) [15, 16, 50], можно четко определить влияние климата и уров- ня содержания нефтепродуктов в морской воде на биоразнообразие и распределение макрофитов. Выявив эти закономерности можно построить прогностические модели "поведения" фитоценозов и дать рекомендации по оптимальному управлению добычей биоресурсов, что может существенно влиять на социально-экономическую ситуацию конкретных прибрежных территорий российского Юга.

В настоящее время международными организациями принята схема разделения прибрежных вод Мирового океана на 64 БМЭ, в пределах которых сосредоточено более $90 \%$ биоресурсов [50]. Для исследования БМЭ применяют модульную систему, включающую пять блоков: (1) биологическое разнообразие и продуктивность; (2) промысел; (3) загрязнение, состояние морской среды, влияние на биоту; (4) биоиндикаторы и управление прибрежными экосистемами; (5) социально-экономическая ситуация, экосистемные услуги. При этом для приокеанических районов приоритетной задачей в БМЭ являются устойчивое ведение рыболовства и ведение добы- 
чи других водных биоресурсов на основе экосистемных принципов. В пределах российской экономической зоны находятся 12 признанных на международном уровне БМЭ, одна из которых, Черное и Азовское моря, рассматривается в данной работе. Каспийское море не рассматривается в концепции БМЭ и не выделяется в отдельный район, так как не имеет прямой связи с Мировым океаном и обладает особым статусом "море-озеро". Но, тем не менее, Каспийское море является водоемом, в акватории которого сходятся интересы 5-ти государств (Российская Федерация, Азербайджан, Казахстан, Туркменистан, Иран), ведется активная добыча биоресурсов и полезных ископаемых. По всем признакам Каспийское море соответствует критериям БМЭ, поэтому, на наш взгляд, к нему применимы подходы, разработанные в рамках концепции БМЭ.

На основе обширной базы океанографических данных [14] выделены факторы, имеющие цикличность и влияющие на динамику сообществ макрофитов: для Черного моря - температура поверхностного слоя и прозрачность воды; для Азовского моря - соленость и ледовый режим; для Каспийского моря - соленость, уровенный и ледовый режим северной части акватории.

Цель работы - используя методологию концепции Больших морских экосистем (БМЭ), показать влияние климатических изменений и уровня содержания нефтепродуктов в морской воде на биоразнообразие и распределение макрофитов.

\section{МАТЕРИАЛЫ И МЕТОДЫ}

Для оценки современного состояния фитобентоса использован полевой материал, собранный в 2000-2014 гг. в Азовском море, российском прибрежье Черного и Каспийского морей, включая более 800 количественных и качественных проб из рейсов НИС “Денеб”, НИС “Профессор Панов”, т/х “Курс". Для анализа многолетней динамики изменений флористического состава, распределения и биомассы макрофитов использованы опубликованные данные [3-6, 22, 23, 28-31, 41, 43].

\section{РЕЗУЛЬТАТЫ И ОБСУЖДЕНИЕ}

\section{Видовое разнообразие и распределение макрофитобентоса. Влияние климатических изменений и загрязнения Азовское море}

Для Азовского моря в современный период выявлено 17 видов зеленых, 5 видов бурых и 23 вида красных водорослей [36]. Характерно распределение водорослей вдоль градиента солености: в Таганрогском заливе доминируют зеленые водоросли родов Ulva, Cladophora, Rhizoclonium, Chaetomorpha, на остальной части Азовского моря и Керченского пролива преобладают морские мак- роводоросли из родов Ulva, Chaetomorpha, Ceramium, Polysiphonia. В юго-западной части Азовского моря к твердым естественным субстратам приурочены сообщества красных (Ceramium, Polysiphonia) и бурых (Cystoseira) водорослей, к рыхлым - морские травы (Zostera marina, Z. noltii) и харовые водоросли.

В настоящее время произошли изменения в соотношении основных групп водорослей в Азовском море, что связано с колебаниями солености, низкими температурами в зимний период [14, 17], и антропогенной деятельностью (зарегулирование и изъятие речного стока). В условиях резкого снижения пресного стока с 2010 г. и увеличения солености Азовского моря (в 2016 г. до 15\%о в центральной части моря) важную роль играет адвекция черноморских вод, которая развивается при определенных гидрометеорологических условиях (югозападных ветрах свыше 20 м/с) и приводит к катастрофическим нагонам в восточной части Таганрогского залива [13]. При указанных условиях черноморские макрофиты или их спороносные части могут в течение нескольких часов преодолевать расстояние от Керченского пролива до Таганрогского залива, это является существенным фактором для инвазий видов из Черного моря в Азовское море. При увеличении солености возрастает видовое разнообразие в сообществах макроводорослей Азовского моря. Для Таганрогского залива значение индекса Шеннона равно 0.65 , прибрежной части Азовского моря - 1.04, Таманского залива -1.38 .

Макроводоросли Азовского моря представлены мезо- и полисапробными видами, что подтверждает мезотрофный статус Азовского моря. Отметим, что в Азовском море увеличилось количество новых видов полисапробной группы из рода Ulva.

До начала 2000-х годов область распространения крупных бурых водорослей Cystoseira barbata и C. crinita была ограничена Керченским проливом. По нашим данным ареал Cystoseira в 20132015 гг. расширился до Казантипского залива, что связано с увеличением солености в последние годы. Другой пример активного осваивания новых биотопов - морские травы Z. marina и $Z$. noltii, которые с 2013 г. проникают в Таганрогский залив и встречаются в Ейском лимане, вытесняя пресноводные и солоноводные виды трав из рода Potomogeton, ранее формировавших заросли с биомассой от 1 до $6 \mathrm{kг} / \mathrm{M}^{2}$. При этом происходит существенная перестройка сложившихся трофических связей в сообществах донных беспозвоночных и рыб.

\section{Черное море}

В настоящее время в Черном море насчитывается более 380 видов макроводорослей, в том числе в российской части от 114 до 151 видов [30, 37, 


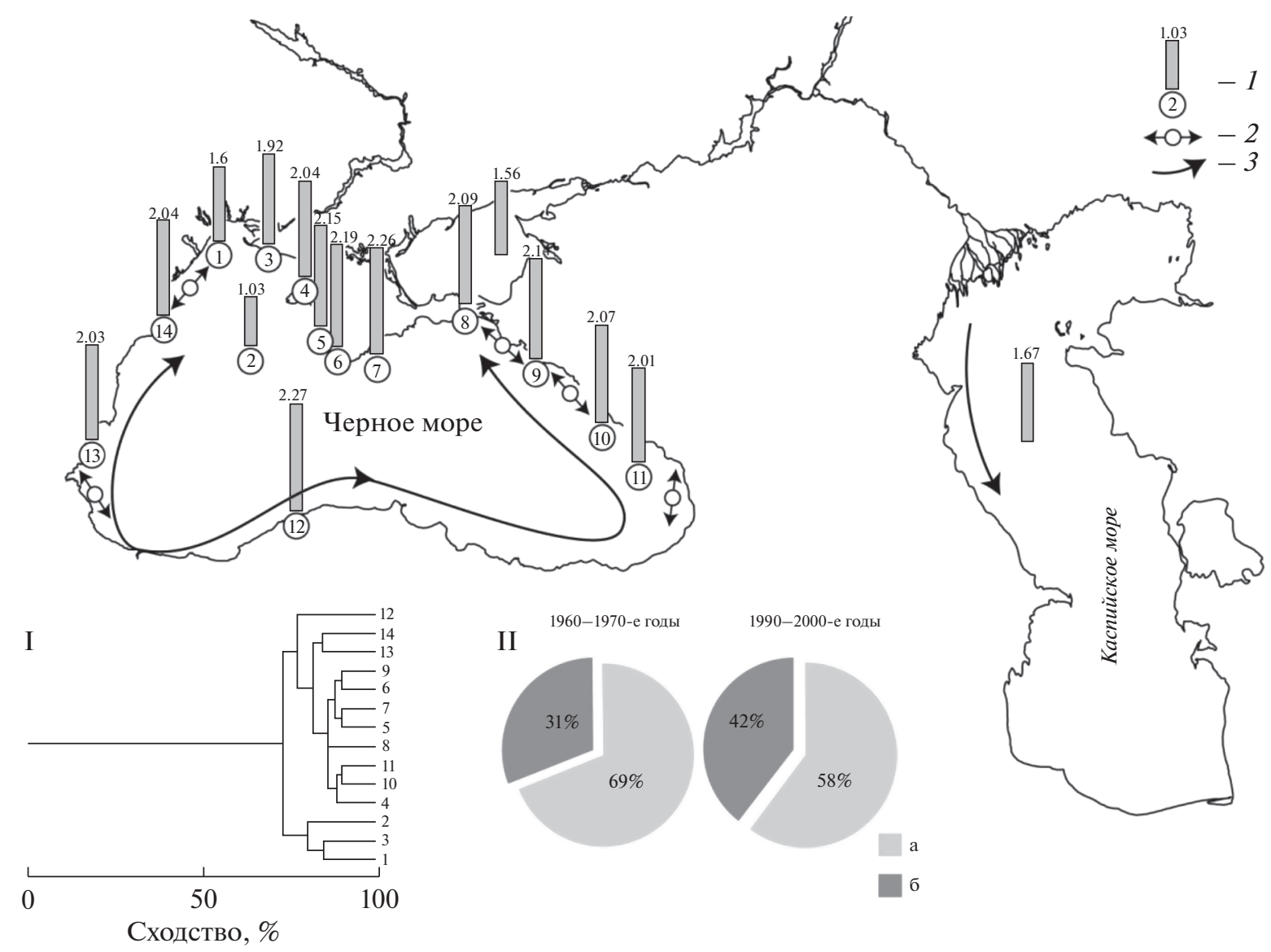

Рис. 1. Карта-схема видового сходства (индекс Шеннона) фитоценозов различных районов на акватории южных морей (1), вероятные пути инвазии водорослей с течениями (2) и из портовых акваторий (3) [14].

Обозначения: 1 - Одесский берег; 2 - филлофорное поле Зернова; 3 - Егорлыцко-Тендровско-Джарылгачско-Перекопский район; 4 - Каркинитский залив; 5 - Тарханкутско-Севастопольский берег; 6 - Севастопольская бухта; 7 Южный берег Крыма; 8 - Прикерченский район; 9 - Новороссийская бухта; 10 - северо-восточный берег; 11 - юговосточный берег; 12 - побережье Турции; 13 - побережье Болгарии; 14 - побережье Румынии. На врезке I - дендрограмма видового сходства водорослей из различных районов Черного моря. На врезке II - соотношение водорослей холодноводного (а) и тепловодного (б) комплексов Черного моря.

41, 48]. Состав флоры значительно вырос по сравнению с 1970-ми годами, большинство находок новых видов, также как и максимальное видовое разнообразие, приходится на турецкий и крымский участок моря. В 1960-1970-е годы преобладал холодноводный комплекс водорослей, с доминированием широко-бореальных видов [6] (рис. 1). В 2000-е годы наметилась четкая тенденция к увеличению доли тепловодного комплекса, с преобладанием с бореально-тропических и субтропических элементов [34], во флоре Черного моря аналогичные явления отмечались в начале XXв.

В последнее время здесь часто обнаруживаются новые виды водорослей - представителей тепловодной флоры $[41,48]$. Исключением является одесское прибрежье, где отмечены находки вселенцев из северной Атлантики и субарктики - бу- рых водорослей Desmarestia viridis и Chorda tomentosa, образующих совместные фитоценозы [24].

Также отмечается значительное уменьшение глубины распространения прикрепленных водорослей $[4-5,23,28]$, в том числе и цистозировых, с которыми связан основной комплекс водорослей-эпифитов Черного моря. Антропогенная деятельность (добыча водорослей, строительство в береговой зоне, загрязнение) оказывает значительное влияние на состав и глубинное распределение водорослей. Особенно явно такое воздействие отмечено для фитобентоса Новороссийской бухты, где разнообразие фитобентоса к концу 2000-х годов уменьшилось в 1.5 раза в сравнении с 1970-ми годами [35, 37], в основном за счет практически полного исчезновения холодноводной группы водорослей. В настоящее время здесь преобладают поли- и мезосапробные виды 
тепловодного комплекса. Значительно (в среднем в 3 раза по сравнению с 1960-ми годами) сократились площади распространения цистозиры - основного эдификатора и средообразующего вида зарослей средиземноморского типа. При этом биомасса цистозиры снизилась в 10 и более раз: с $14 \mathrm{кг} / \mathrm{M}^{2}$ в 1960-х годах до $0.1 \mathrm{кг} / \mathrm{M}^{2}$ в 2010-е годы [35], на глубинах до 1.5 м эти водоросли исчезли полностью. В настоящее время на большей части прибрежной зоны Новороссийской бухты растительные сообщества формируются короткоцикличными сезонными видами.

\section{Каспийское море}

В 1970-е годы список макроводорослей Каспийского моря насчитывал 63 вида, из них 29 видов зеленых, 13 - бурых и 21 - красных водорослей [6]. В ходе наших исследований обнаружено 36 видов макроводорослей, 3 вида морских трав [34]. Выявлено, что соотношение основных групп водорослей зависит от уровня и солености моря. В последние годы соотношение групп водорослей изменилось, количество видов зеленых водорослей возросло. По видовому богатству макроводорослей Каспийское море занимает промежуточное положение между Азовским и Черным морями. Основу каспийской морской флоры составляют зеленые водоросли родов Ulva, Cladophora, Ulothrix и красные водоросли родов Polysiphonia, Laurencia, Ceramium. По географическому составу флора Каспийского моря является широко-бореальной, но наличие 2 эндемичных родов и 8 эндемиков делает этот водоем уникальным $[6,8]$.

Для Северного Каспия и западного берега Среднего Каспия отмечено интенсивное развитие Ulva, Cladophora, Ceramium, что может свидетельствовать об увеличении уровня трофности морских вод, в том числе и из-за попадания в воду углеводородов при добыче нефти. Увеличение доли эврибионтных водорослей обусловлено понижением солености в последние годы, как в Каспийском море в целом, так и северной его части [20]. Изменение температурного режима северо-каспийских вод, по-видимому, не приведет к увеличению тепловодного комплекса водорослей, так как повторяемость суровых зим возрастает [12].

На большей части акватории Северного Каспия на глубинах 1-2 м биомасса водных цветковых растений не превышает 0.5-3 кг $/ \mathrm{M}^{2}$ (до 10 кг/м²). Красные водоросли Polysiphonia и Laurencia на глубинах до 10-15 м формируют на ракушечниках обширные поля с биомассой более $1 \mathrm{kг} / \mathrm{M}^{2}$, но такие участки немногочисленны и локализованы на границе со Средним Каспием и вдоль его западного побережья.

Изменения в фитобентосе южных морей России невозможно объяснить только влиянием за- грязнения, в том числе нефтяного, или антропогенной деструкцией, хотя именно этим ранее объясняли трансформацию фитоценозов южных морей $[4,6,22,23,41]$. Ведущую роль, на наш взгляд, играют климатические изменения в последние десятилетия: в Черном море потепление поверхностного слоя вод [46] и снижение прозрачности морской воды [11], обусловленное развитием кокколитофорид [10, 21], в Азовском море колебания солености, в Каспийском море - изменения солености и уровня моря.

\section{Запасы и промысел}

\section{Азовское море}

Официально добыча водорослей и трав в Азовском море (российский сектор) не ведется. Небольшой объем выброшенной травы Zostera камки, собирается у берегов Украины, ориентировочный объем изъятия, зачастую нелегального, составляет не более 100 т. Основной запас бурой водоросли Cystoseira (2 вида) в российских водах Черного моря находится в районе Туапсе-Анапа. По оценке А.А. Калугиной-Гутник [6] общий запас Cystoseira в советской части моря в середине 1970-х годов составлял 1 млн т, объем допустимого изъятия определялся в 300 тыс. т. Оценка допустимого улова (ОДУ) для бурых водорослей Cystoseira постоянно снижается: с 10 тыс. т в 2005 г., 8 тыс. т в 2015 г. [51]. При этом рекомендованный объем для изъятия составил в 2017 г. 100 т, а в $2018-$ всего 3.88 т [51]. ОДУ для морских трав Zostera (2 вида), основные запасы которой сосредоточены в Таманском заливе, оценивается в последние годы в 70 тыс. т, при этом в 2018 г. рекомендовано к изъятию всего 200 т [51]. Отметим, что более $90 \%$ разрешенного объема изъятия водорослей и трав в настоящее время не осваивается. Вероятно, необходимо введение временного (до 5 лет) запрета на добычу Cystoseira и Zostera в южных морях России [23].

\section{Черное море}

Примером совместного воздействия изменений климата и неразумной хозяйственной деятельности является деградация филлофорного поля Зернова. Начиная с 1960-х годов деструктивные изменения филлофорного поля Зернова связывались исключительно с перепромыслом красных водорослей [6], антропогенной сукцессией фитосообществ [23]. Однако, сопоставляя динамику запасов филлофоры с колебаниями температуры и прозрачности в западной части Черного моря (рис. 2), видно, что катастрофическое снижение запасов, отмеченное в 1940-х годах, увязывается с предшествующим периодом потепления, промысел в эти годы еще не был столь масштабен. В 1950-х годах на фоне наступившего похолодания видно некоторое восстановление запасов филлофо- 


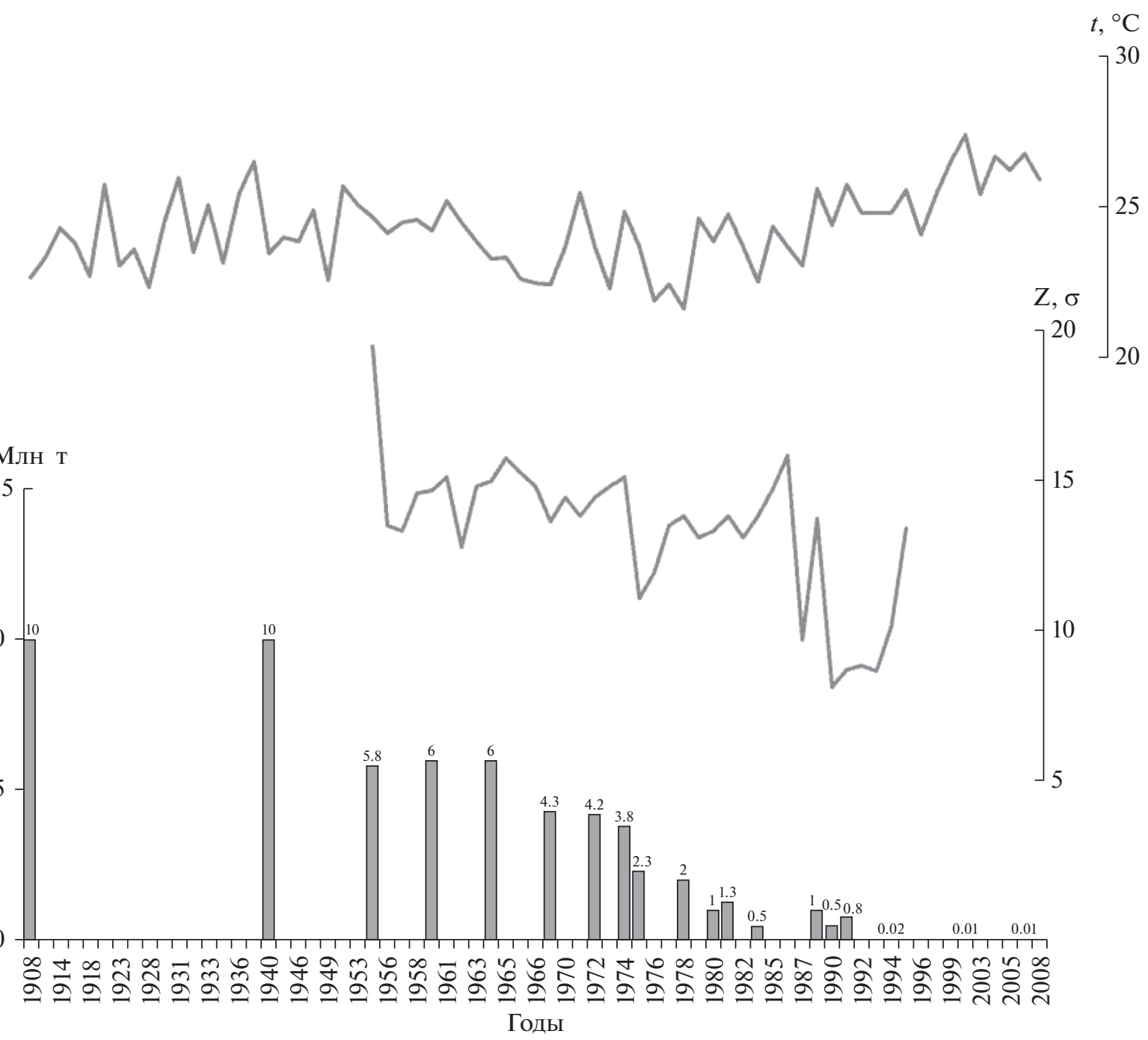

Рис. 2. Многолетняя динамика запасов красных водорослей филлофорного поля Зернова [23], температура поверхностного слоя (август) [46]; прозрачность морской воды в глубоководной части моря [11].

ры. Но активный промысел в 1960-1980-е годы окончательно подорвал существующие запасы водорослей, повышение температуры и снижение прозрачности воды лишь усугубило этот процесс. Отметим, что некоторые признаки восстановления запасов, отмеченные в конце $1990-x$ начале 2000 -х годов [25, 42] можно увязать как с прекращением промысла, так и с периодом похолодания и увеличения прозрачности морской воды, отмеченными в это время. Несмотря на создание природного заказника в Украине в 2008 г. на “остатках" филлофорного поля Зерного, при первых признаках восстановления запасов, началось хищническое истребление биоресурсов. Только воссоединение Крыма с Россией в 2014 г. и введение пограничного режима прекратило браконьерский промысел биоресурсов, в том числе донными тралами.

\section{Каспийское море}

В северной части Каспийского моря запасы Z. noltii в начале 1940 -х годов составляли 700 тыс. т [9]. Более поздние оценки запасов биомассы Z. noltii не проводились, но, основываясь на данных В.В. Громова [4], их можно ориентировочно принять равными около 200 тыс. т для Северного и западной части Среднего Каспия. Исследования [43] показали, что в середине 2000-х годов рост запасов $Z$. noltii по сравнению с 1980-ми годами [4] увеличился в 1.5-2 раза, особенно в районе о-вов Тюлених возле казахского берега.

\section{Индикаторные виды и управление}

На примере двух массовых видов морских трав Z. noltii и Stuckenia pectinata (=Potamogeton pectinatus) Северного Каспия проведены модельные рас- 


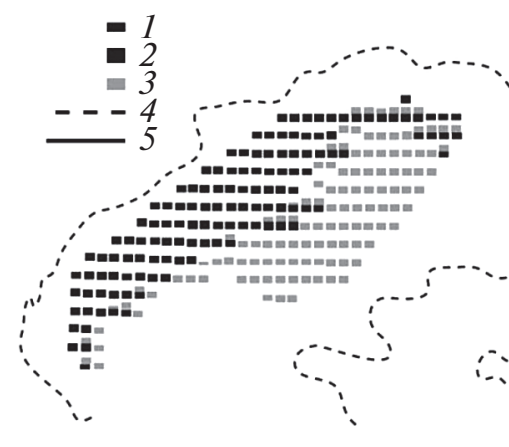

1935 г.

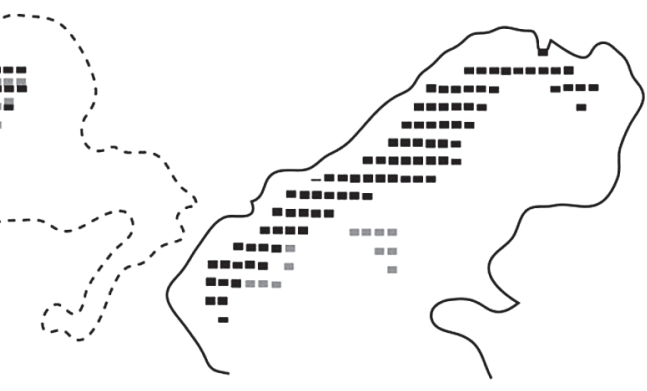

1977 г.

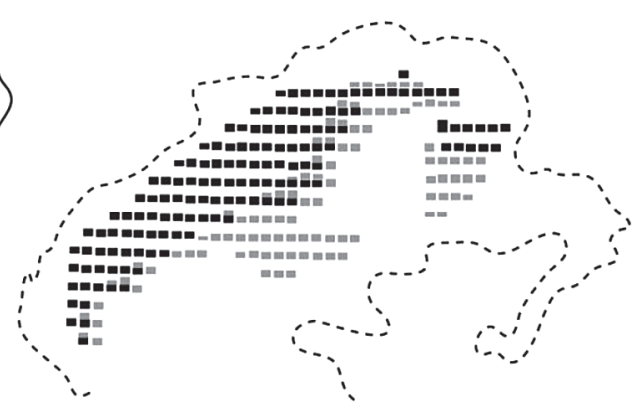

2010 г.

Рис. 3. Визуализация результатов модельных расчетов пространственной динамики биомассы морских трав (1 кг/м2) (1) Stuckenia pectinata (2) и Zostera noltii (3) Северного Каспия, где (4, 5) границы моря [34].

четы по оценке влияния изменения уровня моря и сопряженных факторов на пространственное распределение [34]. Указанные виды выбраны в связи с тем, что у них при определенных условиях может быть "перекрывание" местообитаний и как следствие, конкуренция за субстрат, свет и питательные вещества. Оба вида предпочитают одни и те же глубины от 0.5 до 3 м, но Z. noltii менее чувствительна к колебаниям солености, a St. pectinata более восприимчива к снижению прозрачности морской воды. Пространственно-детализированная модель показывает, что при снижении уровня Каспийского моря происходит исчезновение промыслового вида Z. noltii на небольших глубинах и его локализация в центральной части на глубинах более 10 м (рис. 3). Граница распространения рдеста сдвигается в сторону меньших глубин, площадь покрытия уменьшается в более чем 2 раза. Аналогичная сукцессия описана для лиманов азербайджанского прибрежья [7]. В настоящее время существует возможность для расширения зоны распространения и увеличения запасов морских трав в Северном и Среднем Каспии.

В условиях колебания уровня Каспийского моря важную роль играет изменение площади, занятой прибрежно-водной растительностью (ПВР), в основном тростника южного Phragmites australis. По результатам натурных наблюдений, к началу 2000-х годов площадь ПВР в авандельте значительно сократилась, что привело к перераспределению водоплавающих птиц, большая часть популяций которых переместилась в глубь дельты Волги, что снизило риски гибели для популяций водоплавающих птиц при возможных разливах нефти [1-2].

Морские макроводоросли - один из биологических компонентов в системе производственного мониторинга нефтегазовых компаний [44-45]. Распоряжением Минприроды РФ от 22.09.2015 № 25-p “Об утверждении перечня видов флоры и фауны, являющихся индикаторами устойчивого состояния морских экосистем Арктической зоны
Российской Федерации” был утвержден перечень видов водорослей, которые являются индикаторами устойчивого развития арктических экосистем. Список насчитывает 12 видов макроводорослей и 1 вид морской травы. Это первый федеральный документ, в котором признается роль морских водорослей для устойчивого развития Арктики. Необходима разработка нормативных актов в области сохранения разнообразия макрофитобентоса южных морей России, куда должны быть включены индикаторные виды: промысловые (Cystoseira, Phyllophora, Zostera), эндемики (Laurencia coronopus, Chaetomorpha zernovii, Cladophora siwaschensis, Ulva maeotica, Dasya apiculata) и исчезающие виды (Gracelaria dura, Desmotrichum punctaroides, Porphyra ssp.).

\section{Загрязнение и его влияние на макроводоросли}

Из основных загрязнителей наиболее значимое влияние на развитие морской биоты в южных морях России (особенно Черного моря) оказывают нефтяные углеводороды, действие остальных загрязняющих веществ (тяжелые металлы, пестициды, радиоактивные элементы) не имеют столь глобального и выраженного значения [49]. Наибольшие концентрации нефтепродуктов в течение года характерны для районов Новороссийска и Туапсе (до 4.90 мг/л) [18-19], где имеются крупные нефтяные порты и наиболее напряженный трафик морских перевозок нефти. Курортные акватории Анапы и Геленджика чище в весенний период (менее 0.68 мг/л); летом и осенью концентрация углеводородов нефти возрастает в два и более раза [18-19].

Воздействие эмульсии нефти на макрофиты происходит непосредственно в водной толще, а пленки - на мелководной части прибрежья, в супралиторальной зоне, где обитает около 100 видов черноморских водорослей $[6,30]$. Непосредственный контакт черноморских водорослей с пленкой 
нефти приводит к быстрой гибели зрелых талломов [6, 26, 27, 39]. В проведенных экспериментах проростки массовых видов черноморских водорослей $C$. barbata, U. intestinalis, $C$. virgatum, Polysiphonia sp. показали высокую устойчивость к действию эмульсии легкой нефти и нефтепродуктов, нормально развиваясь при концентрациях до 50 мг/л, бо́льшие концентрации токсикантов подавляли развитие водорослей. Концентрации нефти и дизельного топлива до 10 мг/л стимулировали рост проростков водорослей. Отметим, что использованные концентрации нефти и нефтепродуктов в десятки раз превышали предельнодопустимую концентрацию (0.05 мг/л), принятую для рыбохозяйственных водоемов, но соответствовали современному уровню нефтяного загрязнения Черного моря в отдельных акваториях и бухтах. По степени устойчивости к воздействию нефти и нефтепродуктов черноморские водоросли можно расположить (по убыванию) следующим образом: Cystoseira barbata $\rightarrow$ Ulva intestinalis $\rightarrow$ Ceramium virgatum $\rightarrow$ Polysiphonia sp. Сходные результаты получены для макроводорослей эстуарных экосистем Баренцева моря [32, 33, 39-40]. Водоросли умеренно загрязненных акваторий оказываются более приспособленными к воздействию углеводородов нефти, чем из чистых районов [38], следовательно, при крупных техногенных авариях и попадании в море нефти устойчивость сообществ водорослей умеренно загрязненных прибрежий будет выше, чем в чистых акваториях. Применение водорослей из умеренно загрязненных местообитаний для плантаций-биофильтров позволит эффективней использовать этот подход в фиторемедиации [38].

На наш взгляд, разовая катастрофа скажется не столь значительно на популяциях водорослей, как хроническое поступление нефтетоксикантов в условиях заливов и лиманов. Структурный "скелет" сообщества сохранится, но могут исчезнуть чувствительные к воздействию нефти группы животных и микроводорослей. Это может привести к дисбалансу в прибрежной экосистеме и повлиять на продуктивность и распределение макроводорослей. Вероятно, сукцессионные процессы в сообществах водорослей будут развиваться аналогично наблюдаемым в Новороссийской бухте.

\section{ЗАКЛЮЧЕНИЕ}

Для управления морскими биоресурсами в южных морях России важен прогноз состояния макрофитобентоса на ближайшие годы. Выявленные в результате экспериментальных исследований индивидуальные различия в толерантности макроводорослей к нефтепродуктам, анализ перестройки фитосообществ под воздействием изменений климата позволили представить прогноз состояния макрофитобентоса эстуарных экосистем южных морей России при дальнейшем воздействии климатических изменений и уровне нефтяного загрязнения:

- в Черном море в долговременной перспективе (до середины XXI в.) будет увеличиваться доля тепловодной флоры. Представители холодноводного комплекса водорослей будут сужать ареалы, переходить в разряд редких и исчезающих видов;

- в Азовском море в ближайшие 10 лет будет и дальше происходить расширение зоны обитания черноморской флоры, формирование типичных черноморских сообществ;

- в Каспийском море в условиях стабильного уровня моря и солености существенных изменений для фитобентоса наблюдаться не будет, но возможно расширение зоны обитания промыслового вида Zostera;

- в Новороссийской бухте процесс трансформации фитосообществ будет продолжаться, что приведет в течение 10-15 лет к практически полному исчезновению типичных черноморских сообществ с участием Cystoseira u Phyllophora.

Долговременные изменения температуры, солености и прозрачности морской воды в значительной степени влияют на функционирование фитобентоса. Нефть и нефтепродукты при попадании в морскую воду способны вносить дисбаланс в структуру и функционирование прибрежных экосистем, оказывая дополнительное негативное воздействие на сообщества.

Концепция БМЭ предполагает оценку вклада отдельных компонентов морских систем в общий пул экосистемных “услуг” для экономики прибрежных стран. Для фитобентоса южных морей России в настоящее время такие оценки не проведены. И если вклад от добычи промысловых видов водорослей и трав возможно определить, то стоимость косвенных “услуг” - эстетика в рекреационных зонах, биотоп для фитофильных рыб, потоки вещества и энергии, усвоение $\mathrm{CO}_{2}$ и вклад в его снижение в морях и атмосфере, связывание и удаление из воды и донных отложений биогенных элементов, тяжелых металлов, радионуклидов и т.д. нуждается в дальнейшей проработке.

\section{ФИНАНСИРОВАНИЕ}

Исследования проведены в рамках госсубсидии “Морские биогеосистемы юга России и их водосборы в условиях аридного климата, хозяйственного освоения и современных геополитических вызовов” № AAAA-A18118122790121-5 и РФФИ (проект № 18-29-05078).

\section{БЛАГОДАРНОСТИ}

Автор выражает благодарность академику Г.Г. Матишову за идею подготовки статьи, благодарен анонимному рецензенту за ценные замечания, которые позволили улучшить работу. 


\section{FUNDING}

This research was carried out within the framework of the state-ordered research theme of the Southern Scientific Center of Russian Academy of Sciences "Marine biogeosystems of the south of Russia and their watersheds in the conditions of arid climate, economic development and modern geopolitical challenges" (no. AAAA-A18118122790121-5), and within the framework of the Russian Foundation for Basic Research (project no. 18-29-05078).

\section{ACKNOWLEDGMENTS}

The author is grateful to Academician G.G. Matishov for the idea of article preparing and to the anonymous reviewer for valuable comments that have improved the article.

\section{СПИСОК ЛИТЕРАТУРЫ}

1. Бердников С.В, Маркитан Л.В., Степаньян О.В. Пространственно-детализированная модель многолетней динамики прибрежно-водной растительности и численности водоплавающих птиц устьевой области Волги // Успехи современной биологии. 2009. Т. 129. № 1. С. 80-92.

2. Бердников С.В, Степаньян О.В., Маркитан Л.В. Оценка влияния разливов нефти на распределение прибрежно-водной растительности и водоплавающих птиц Северного Каспия (модельный эксперимент) // Защита окружающей среды в нефтегазовом комплексе. 2018. № 5. С. 14-19.

3. Водоросли / справочник / под ред. С.П. Вассер, Н.В. Кондратьева, Н.П. Масюк. Киев: Наукова Думка, 1989. 608 с.

4. Громов В.В. Макрофитобентос южных морей России. Водоросли северо-кавказского побережья Черного моря, прибрежно-водная растительность Азовского моря и Северного Каспия. Palmarium Academic Publishing. 2012. 337 c.

5. Евстигнеева И.К. Видовой состав и количественная характеристика эпифитов Cystoseira crinita Bory // Альгология. 1993. Т. 3. № 4. С. 52-57.

6. Калугина-Гутник А.А. Фитобентос Черного моря. Киев: Наукова думка, 1975. 245 с.

7. Караева Н.И., Забержинская Э.Б. Динамика Zostera noltii Hornem у азербайджанского побережья Каспия // Вісник ОНУ. 2008. Т. 13. Вип. 4. С. 196-199.

8. Каспийское море: Фауна и биологическая продуктивность. М.: Наука, 1985. 277 с.

9. Киреева М.С. Растительные богатства морей Советского Союза // Растительные ресурсы. 1965. Т. 1. Вып. 3. С. 323-335.

10. Копелевич О.В., Буренков В.И., Вазюля С.В., Шеберcmoв C.B. Проблемы индикации кокколитофоридных цветений по спутниковым данным // Современные проблемы дистанционного зондирования Земли из космоса. 2012. Т. 9. № 5. С. 241-250.

11. Кукушкин А.С., Прохоренко Ю.А., Хорошун С.А. Многолетняя изменчивость прозрачности вод в шельфовых и глубоководных районах Черного моря в XX столетии // Экологическая безопасность прибрежной и шельфовой зон моря. 2013. № 27. C. 243-248.

12. Матишов Г.Г. Влияние изменчивости климатического и ледового режимов на судоходство // Вестн.
Российской академии наук. 2008. Т. 78. № 10. C. 896-902.

13. Матишов Г.Г., Бердников С.В. Экстремальное затопление дельты Дона весной 2013 г. // Изв. РАН. Сер. геогр. 2015. № 1. С. 111-118.

14. Матишов Г.Г., Бердников С.В., Жичкин А.П., Макаревич П.Р., Дженюк С.Л., Кулыгин В.В., Яицкая Н.А., Поважный В.В., Шевердяев И.В., Третьякова И.А., Цыганкова A.E. Атлас климатических изменений в больших морских экосистемах северного полушария (1878-2013). Ростов-Н/Д.: ЮНЦ РАН, 2014. 131 с.

15. Матишов Г.Г., Дженюк С.Л., Жичкин А.П., Моисеeв Д.В. Климат морей Западной Арктики в начале ХХІ века // Изв. РАН. Сер. геогр. 2011. № 3. С. 17-32.

16. Матишов Г.Г., Макаревич П.Р., Моисеев Д.В. Климат и большие морские экосистемы Арктики. Ростов-Н/Д.: ЮНЦ РАН, 2016. 96 с.

17. Матишов Г.Г., Матишов Д.Г., Гаргопа Ю.М., Дашкевич Л.В. Замерзание Азовского моря и климат в начале XXI века // Вестн. Южного научного центра. 2010. Т. 6. № 1. С. 33-40.

18. Матишов Г.Г., Степаньян О.В., Григоренко К.С., Харьковский В.М., Поважный В.В., Сойер В.Г. Особенности гидролого-гидрохимического режима Азовского и Черного морей в 2013 г. // Вестн. Южного научного центра. 2015. Т. 11. № 2. С. 36-44.

19. Матишов Г.Г., Степаньян О.В., Харьковский В.М., Сойер В.Г. Нефтяное загрязнение Азовского и Черного морей растет // Природа. 2016. № 5. С. 64-69.

20. Матишов Г.Г., Яицкая Н.А., Бердников С.В. Особенности внутривекового режима солености Каспийского моря // Доклады АН. 2012. Т. 444. № 2. С. 747-751.

21. Микаэлян А.С., Силкин В.А., Паутова Л.А. Развитие кокколитофорид в Черном море: межгодовые и многолетние изменения // Океанология. 2011. T. 51. № 1. C. 39-48.

22. Мильчакова М.A. Макрофитобентос // Современное состояние биоразнообразия прибрежных вод Крыма (черноморский сектор). Севастополь: ЭКОСИ-Гидрофизика, 2003. С. 152-208.

23. Мильчакова Н.А., Миронова Н.В., Рябогина В.Г. Морские растительные ресурсы // Промысловые биоресурсы Черного и Азовского морей. Севастополь, 2011. С. 117-139.

24. Миничева Г.Г. Новый вселенец в Черном море: бурая водоросль Chorda tomentosa Lyngb. // Альгология. 2015. Т. 25. № 3. С. 323-329.

25. Миничева Г.Г. Современная морфофункциональная трансформация сообщества макрофитов филлофорного поля Зернова // Альгология. 2007. Т. 17. № 2. С. $171-190$.

26. Миронов О.Г. Взаимодействие морских организмов с нефтяными углеводородами. Л.: Гидрометиоиздат, 1985. $127 \mathrm{c.}$

27. Миронов О.Г., Цымбал И.М. Развитие водорослей макрофитов в условиях нефтяного загрязнения // Науч. докл. высш. школы. Биолог. науки. 1975. № 5. С. 53-56.

28. Митясева Н.А., Максимова О.В., Георгиев А.А. Флора макроводорослей северной части российского побережья Черного моря // Экология моря. 2003. Вып. 64. С. 24-28.

29. Морские охраняемые акватории Крыма: научный справочник / под ред. Н.А. Мильчаковой. Симферополь: Н. Оріанда, 2015. 312 с. 
30. Никитина В.Н., Лисовская О.А. Макрофитобентос верхних отделов береговой зоны российского побережья Черного моря // Труды С.-Петербург. о-ва естествоиспыт. Сер. 3. Т. 81. СПб.: СПбГУ, 2013. $132 \mathrm{c}$.

31. Садогурский C.E. К изучению макрофитобентоса у черноморского побережья Керченского полуострова (Крым) // Альгология. 2007. Т. 17. № 3. C. 345-360.

32. Степаньян O.B. Влияние сырой нефти на ранние стадии развития макроводорослей Баренцева моря // Ботанический журн. 2013. Т. 98. № 7. С. 903-912.

33. Степаньян O.B. Воздействие нефтяной пленки на фотосинтез бурых водорослей Баренцева моря // Ботанический журн. 2014. Т. 99. № 10. С. 1095-1100.

34. Степаньян О.В. Макрофитобентос Каспийского моря: разнообразие, распределение, продуктивность // Океанология. 2016. Т. 56. № 3. С. 395-405.

35. Степаньян О.В. Макрофитобентос Новороссийской бухты: деградация в условиях хозяйственной деятельности и климатических изменений // Вестн. КамчатГТУ. 2018. № 4. С. 110-116.

36. Степаньян O.B. Распределение макроводорослей и морских трав Азовского моря, Керченского пролива и Таманского залива // Океанология. 2009. № 3. С. 393-399.

37. Степаньян О.В. Современное разнообразие макроводорослей Азовского, Черного и Каспийского морей // Докл. АН. 2014. Т. 458. № 2. С. 229-232.

38. Степаньян О.В. Хроническое загрязнение повышает устойчивость бурой водоросли Fucus vesiculosus (L.) к действию углеводородов нефти // Защита окружающей среды в нефтегазовом комплексе. 2015. № 2. С. 22-25.

39. Степаньян О.В., Воскобойников Г.М. Влияние нефти и нефтепродуктов на морфо-функциональные особенности морских макроводорослей // Биология моря. 2006. Т. 32. № 4. С. 241-248.

40. Степаньян О.В., Матишов Г.Г., Кулысин В.В. Устойчивость макроводорослей Баренцева моря к нефтяному загрязнению // Наука Юга России. 2017. T. 13. № 3. С. 103-108.

41. Теюбова В.Ф. Разнообразие и экологические особенности макрофитобентоса российского сектора Черного моря. Автореф. ... дис. канд. биол. наук. Краснодар, 2012. 20 с.

42. Ткаченко Ф.П., Третьяк И.П., Костылев Э.Ф. Макрофитобентос филлофорного поля Зернова в современных условиях (Черное море, Украина) // Альгология. 2008. Т. 18. № 4. С. 423-431.
43. Чиженкова О.А., Зайцев В.Ф. Особенности формирования и распределения макрофитов и зообентоса на различных типах грунта Северном Каспии // Вестн. АГТУ. Сер. Рыбное хозяйство. 2011. № 2. C. 69-73.

44. Шавыкин А.А., Ильин Г.В. Оценка интегральной уязвимости акватории Баренцева моря от нефтяного загрязнения. Мурманск: ММБИ КНЦ РАН, 2010. $110 \mathrm{c}$

45. Шахин Д.А., Пинаев В.Е. Оценка современного состояния окружающей среды в рамках экологического сопровождения проектов. М.: МАКС Пресс, 2013. $214 \mathrm{c}$.

46. Kontoyiannis H., Papadopoulos V., Kazmin A., Zatsepin A., Georgopoulos D. Climatic variability of the sub-surface sea temperatures in the Aegean-Black Sea system and relation to meteorological forcing // Climate Dynamics. 2012. V. 39. № 6. P. 1507-1525.

47. Merzouka A., Johnson L.E. Kelp distribution in the northwest Atlantic Ocean under a changing climate // J. of Experimental Marine Biol. and Ecol. 2011. V. 400. № 1-2. P. 90-98.

48. Minicheva G., Afanasyev D., Kurakin A. 2014. Black Sea Monitoring Guidelines. Macrophytobenthos. http://emblasproject.org/wp-content/uploads/2013/12/Manual_macrophytes_EMBLAS ann.pdf

49. Oguz $\bar{T}$., Velikova $V$. Abrupt transition of the northwestern Black Sea shelf ecosystem from a eutrophic to an alternative pristine state// Marine ecology. Progress series. 2010. V. 405. P. 231-242.

50. Sherman K., Sissenwine M., Christensen V., Duda A., Hempel G., Ibe C., Levin S., Lluch-Belda D., Matishov G., McGlade J., O'Toole M., Seitzinger S., Serra R., Skjoldal H.-R., Tang Q., Thulin J., Vandeweerd V., Zwanenburg K.A. Global movement toward an ecosystem approach to management of marine resources // Marine Ecology - Progress Series. 2005. V. 300. P. 275-279.

51. Приказ Минстерства сельского хозяйства РФ от 27 октября 2017 г. № 533 “Об утверждении общего допустимого улова водных биологических ресурсов во внутренних морских водах Российской Федерации, территориальном море Российской Федерации, на континентальном шельфе Российской Федерации и в исключительной экономической зоне Российской Федерации, в Азовском и Каспийском морях на 2018 год”. https://fishnews.ru/_img/docs/1132/prikaz_msh_-_533_ot_2710-17_ob_utv-_odu_morskoe_2018_god.pdf (дата обращения 10.01.2020).

\title{
Macrophytobenthos in the Concept of Large Marine Ecosystems: The Southern Seas of Russia
}

\author{
O. V. Stepanyan" \\ Federal Research Centre "Southern Scientific Centre of the RAS", Rostov-on-Don, Russia \\ ${ }^{\#}$--mail: step@ssc-ras.ru
}

The concept of Large Marine Ecosystems assesses the state and dynamics of long-term changes in qualitative and quantitative indicators of macrophytobenthos (macroalgae and seagrasses) of the Russian southern seas. It is shown that changes in the species composition and spatial distribution of macrophytobenthos of marine ecosystems (the Sea of Azov, the Caspian Sea) are associated with fluctuations in salinity and sea level. For 
the Caspian Sea northern part (Russian sector) since the early 2000s. there is an increase in the share of saprobial complex of green and red algae, the expansion of the habitat of Zostera noltii, due to changes in salinity and water level in the reservoir. The greatest destruction of macrophytobenthos in the Black Sea observed in marine estuaries, port areas, including in Novorossiysk Bay. The most resistant to the action of petroleum products are brown algae (Cystoseria), less green (Ulva) and red (Ceramium). Mathematical models of the Northern Caspian water and coastal-water vegetation response to changes in water level and salinity are constructed. These models adequately reflect the ongoing natural processes and allow to predict the impact of climate and anthropogenic load (economic activity) on aquatic biological resources. The necessity of the macrophytobenthos ecosystem "services" assessment for the Russian economy is pointed out.

Keywords: macrophytobenthos, marine macroalgae, seagrass, Large Marine Ecosystems, climate change, pollution, fishing

\section{REFERENCES}

1. Berdnikov S.V, Markitan L.V., Stepan'yan O.V. Spatially detailed model of long-term dynamics of coastal and aquatic vegetation and the number of waterfowl in the mouth of the Volga region. Usp. Sovr. Biol., 2009, vol. 129 , no. 1, pp. 80-92. (In Russ.).

2. Berdnikov S.V, Stepan'yan O.V., Markitan L.V. Assessment of the impact of oil spills on the distribution of coastal aquatic vegetation and waterfowl in the North Caspian (model experiment). Zashchita Okruzhayushchei Sredy v Neftegazovom Komplekse, 2018, no. 5, pp. 14-19. (In Russ.).

3. Vodorosli [Algae]. Vasser S.P., Kondrat'eva N.V., Masyuk N.P., Eds. Kiev: Naukova Dumka Publ., 1989. $608 \mathrm{p}$.

4. Gromov V.V. Makrofitobentos yuzhnykh morei Rossii. Vodorosli severo-kavkazskogo poberezh'ya Chernogo morya, pribrezhno-vodnaya rastitel'nost' Azovskogo morya i Severnogo Kaspiya [Macrophytobenthos of the Southern Seas of Russia. Algae of the North Caucasian Black Sea Coast, Coastal Aquatic Vegetation of the Sea of Azov and the North Caspian]. Palmarium Akad. Publ., 2012. $337 \mathrm{p}$.

5. Evstigneeva I.K. Species composition and quantitative characteristics of Cystoseira crinita Bory epiphytes. $\mathrm{Al}$ gologiya, 1993, vol. 3, no. 4, pp. 52-57. (In Russ.).

6. Kalugina-Gutnik A.A. Fitobentos Chernogo morya [Phytobentos of the Black Sea]. Kiev: Naukova Dumka Publ., 1975. 245 p.

7. Karaeva N.I., Zaberzhinskaya E.B. Dynamics of Zostera noltii Hornem off the Azerbaijani Caspian coast. Visnyk $O N U, 2008$, vol. 13, no. 4, pp. 196-199. (In Russ.).

8. Kaspiiskoe more: Fauna i biologicheskaya produktivnost' [The Caspian Sea: Fauna and Biological Productivity]. Moscow: Nauka Publ., 1985. 277 p.

9. Kireeva M.S. Plant wealth of the seas of the Soviet Union. Rastit. Resur., 1965, vol. 1, no. 3, pp. 323-335. (In Russ.).

10. Kopelevich O.V., Burenkov V.I., Vazyulya S.V., Sheberstov S.V. Problems of detection of coccolithophore blooms from satellite data. Sovrem. Probl. Dist. Zond. Zemli Kosmosa, 2012, vol. 9, no. 5, pp. 241-250. (In Russ.).

11. Kukushkin A.S., Prokhorenko Yu.A., Khoroshun S.A. Long-term variability of water transparency in the shelf and deep-sea areas of the Black sea in the twentieth century. Ekol. Bezopasnost' Pribrezhnoi i Shel'fovoi Zon Morya, 2013, no. 27, pp. 243-248. (In Russ.).
12. Matishov G.G. Effect of changeability of climatic and ice conditions on shipping. Vestn. Ross. Akad. Nauk, 2008, vol. 78, no. 10, pp. 896-902. (In Russ.).

13. Matishov G.G., Berdnikov S.V. Extreme flooding of the Don Delta in spring 2013. Izv. Akad. Nauk, Ser. Geogr., 2015, no. 1, pp. 111-118. (In Russ.). doi 10.15356/0373-2444-2015-1-111-118

14. Matishov G.G., Berdnikov S.V., Zhichkin A.P., Dzhenyuk S.L., Smolyar I.V., Kulygin V.V., Yaitskaya N.A., Povazhniy V.V., Sheverdyaev I.V., Kumpan S.V., Tret'yakova I.A., Tsygankova A.E., D'yakov N.N., Fomin V.V., Klochkov D.N., Shatohin B.M., Plotnikov V.V., Vakul'skaya N.M., Luchin V.A., Kroots A.A. Atlas of Climatic Changes in Large Marine Ecosystems of the Northern Hemisphere (1878-2013). Matishov G.G., Sherman K., Levitus S., Eds. NOAA Atlas NESDIS 78. 131 p. doi 10.7289 /V5Q52MK5

15. Matishov G.G., Dzhenyuk S.L., Zhichkin A.P., Moiseev D.V. The climate of the seas of the Western Arctic in the early XXI century. Izv. Akad. Nauk, Ser. Geogr., 2011, no. 3, pp. 17-32. (In Russ.).

16. Matishov G.G., Makarevich P.R., Moiseev D.V. Klimat i bol'shie morskie ekosistemy Arktiki [Climate and Large Marine Ecosystems of the Arctic]. Rostov-onDonu: Yuzhn. Nauchn. Tsentr Akad. Nauk, 2016. 96 p.

17. Matishov G.G., Matishov D.G., Gargopa Yu.M., Dashkevich L.V. The freezing of the Azov sea and the climate of the early XXI century. Vestn. Yuzhn. Nauchn. Tsentra, 2010, vol. 6, no. 1, pp. 33-40. (In Russ.).

18. Matishov G.G., Stepan'yan O.V., Grigorenko K.S., Khar'kovskii V.M., Povazhnyi V.V., Soier V.G. Specific features of hydrological and hydrochemical conditions of the Sea of Azov and the Black Sea in 2013. Vestn. Yuzhn. Nauchn. Tsentra, 2015, vol. 11, no. 2, pp. 36-44. (In Russ.).

19. Matishov G.G., Stepan'yan O.V., Khar'kovskii V.M., Soier V.G. Oil pollution of the Azov and the Black seas is growing. Priroda, 2016, no. 5, pp. 64-69. (In Russ.).

20. Matishov G.G., Yaitskaya N.A., Berdnikov S.V. Peculiarities of the centennial salinity regime of the Caspian Sea. Dokl. Earth Sci., 2012, vol. 444, no. 2, pp. 747-751. doi 10.1134/S1028334X12060141

21. Mikaelyan A.S., Silkin V.A., Pautova L.A. Coccolithophorids in the Black Sea: their interannual and longterm changes. Oceanology, 2011, vol. 51, no. 1, pp. 3948. doi 10.1134/S0001437011010127

22. Mil'chakova M.A. Macrophytobentos. In Sovremennoe sostoyanie bioraznoobraziya pribrezhnykh vod Kryma (chernomorskii sektor) [Current State of Biodiversity of the Coastal Waters of Crimea (Black Sea Sector)]. Sev- 
astopol: EKOSI-Gidrofizika Publ., 2003, pp. 152-208. (In Russ.).

23. Mil'chakova N.A., Mironova N.V., Ryabogina V.G. Marine plant resources. In Promyslovye bioresursy Chernogo i Azovskogo morei [Commercial Bioresources of the Black and Azov Seas]. Sevastopol, 2011, pp. 117139. (In Russ.).

24. Minicheva G.G. New invader in the Black sea: brown algae Chorda tomentosa Lyngb. Algologiya, 2015, vol. 25 , no. 3 , pp. 323-329. (In Russ.).

25. Minicheva G.G. Contemporary morphofunctional transformation of seaweed communities of the Zernov phyllophora field. Algologiya, 2007, vol. 17, no. 2, pp. 171-190. (In Russ.).

26. Mironov O.G. Vzaimodeistvie morskikh organizmov s neftyanymi uglevodorodami [The Interaction of Marine Organisms with Petroleum Hydrocarbons]. Leningrad: Gidrometioizdat Publ., 1985. 127 p.

27. Mironov O.G., Tzymbal I.M. Development of macrophyte algae in conditions of oil pollution. Nauchn. Dokl. Vyssh. Shkoly. Biolog. Nauki, 1975, no. 5. pp. 5356. (In Russ.).

28. Mityaseva N.A., Maksimova O.V., Georgiev A.A. Macroalgae flora of the Northern part of the Russian Black sea coast. Ekologiya Morya, 2003, vol. 64, pp. 24-29. (In Russ.).

29. Morskie okhranyaemye akvatorii Kryma [Marine Protected Waters of Crimea]. Mil'chakova N.A., Ed. Simferopol: Orianda Publ., 2015. 312 p.

30. Nikitina V.N., Lisovskaya O.A. Makrofitobentos verkhnikh otdelov beregovoi zony rossiiskogo poberezh'ya Chernogo morya [Macrophytobenthos of the Upper Parts of the Coastal Zone of the Russian Black Sea Coast]. St. Petersburg: S.-Peterb. Univ., 2013. 132 p.

31. Sadogurskii S.E. On the study of macrophytobenthos off the Black Sea coast of the Kerch Peninsula (Crimea). Algologiya, 2007, vol. 17, no. 3, pp. 345-360. (In Russ.).

32. Stepan'yan O.V. Effect of crude oil on early stages of macroalgae development in the Barents sea. Botan. Zh., 2013, vol. 98, no. 7, pp. 903-912. (In Russ.).

33. Stepan'yan O.V. The oil film influence on photosynthesis of brown algae in the Barents sea. Botan. Zh., 2014, vol. 99, no. 10, pp. 1095-1100. (In Russ.).

34. Stepanian O.V. Macrophytobenthos of the Caspian sea: Diversity, distribution, and productivity. Oceanology, 2016, vol. 56, no. 3, pp. 395-405.

doi 10.1134/S0001437016030218

35. Stepan'yan O.V. Macrophytobenthos of the Novorossiysk Bay (the Black Sea): degradation under conditions of economic activity and climate changes. Vestn. KamchatGTU, 2018, no. 4, pp. 110-116. (In Russ.).

36. Stepan'yan O.V. Distribution of macroalgae and seagrasses in the Azov sea, the Kerch Strait and the Taman Bay. Okeanologiya, 2009, vol. 49, no. 3, pp. 393-399. (In Russ.).

37. Stepan'yan O.V. The modern diversity of macroalgae of the Azov, Black and Caspian seas. Dokl. Akad. Nauk, 2014, vol. 458, no. 2, pp. 229-232. (In Russ.).

38. Stepan'yan O.V. Chronic pollution improves the resistance of Focus vesiculosus (L.) brown algae to the effect of oil hydrocarbons. Zashchita Okruzhayushchei Sredy v Neftegazovom Komplekse, 2015, no. 2, pp. 22-25. (In Russ.).

39. Stepan'yan O.V., Voskoboinikov G.M. Influence of oil and oil products on morphological and functional fea- tures of marine macroalgae. Biologiya Morya, 2006, vol. 32, no. 4, pp. 241-248. (In Russ.).

40. Stepan'yan O.V., Matishov G.G., Kulygin V.V. The stability of macroalgae of the Barents sea to oil pollution. Nauka Yuga Rossii, 2017, vol. 13, no. 3, pp. 103-108. (In Russ.).

41. Teyubova V.F. Diversity and ecological features of macrophytobenthos in the Russian sector of the Black sea. Extended Abstract of Cand. Sci. (Biol.) Dissertation. Krasnodar: Kuban. State Univ., 2012. 20 p.

42. Tkachenko F.P., Tret'yak I.P., Kostylev E.F. Macrophytobenthos of Zernov phyllophora field in present conditions (Black Sea, Ukraine). Algologiya, 2008, vol. 18, no. 4, pp. 423-431. (In Russ.).

43. Chizhenkova O.A., Zaitsev V.F. Peculiarities of macrophyte and zoobenthos development and distribution in different types of sediments in the Northern Caspian. Vestn. Astrakhan. Gos. Tekh. Univ., Ser. Rybnoe Khozyaistvo, 2011, no. 2, pp. 69-73. (In Russ.).

44. Shavykin A.A., Il'in G.V. Otsenka integral'noi uyazvimosti akvatorii Barentseva morya ot neftyanogo zagryazneniya [Assessment of Integrated Vulnerability of the Barents Sea Water Area to Oil Pollution]. Murmansk: Murmansk. Morskoi Biol. Inst. Kol'sk. Nauchn. Tsentra Akad. Nauk, 2010. 110 p.

45. Shakhin D.A., Pinaev V.E. Otsenka sovremennogo sostoyaniya okruzhayushchei sredy $v$ ramkakh ekologicheskogo soprovozhdeniya proektov [Assessment of the Current State of the Environment in the Framework of the Environmental Support of Projects]. Moscow: MAKS Press, 2013. 214 p.

46. Kontoyiannis H., Papadopoulos V., Kazmin A., Zatsepin A., Georgopoulos D. Climatic variability of the sub-surface sea temperatures in the Aegean-Black Sea system and relation to meteorological forcing. Clim. Dyn., 2012, vol. 39, no. 6, pp. 1507-1525.

47. Merzouka A., Johnson L.E. Kelp distribution in the northwest Atlantic Ocean under a changing climate. J. Exp. Mar. Biol. Ecol., 2011, vol. 400, no. 1-2, pp. 90-98.

48. Minicheva G., Afanasyev D., Kurakin A. Black Sea Monitoring Guidelines. Macrophytobenthos. EMBLAS, 2014. Available at: http://emblasproject.org/wp-content/uploads/2013/12/Manual_macrophytes_EMBLAS_ann.pdf (accessed: 10.01.2020).

49. Oguz T., Velikova V. Abrupt transition of the northwestern Black Sea shelf ecosystem from a eutrophic to an alternative pristine state. ?Mar. Ecol. Prog. Ser., 2010, vol. 405, pp. 231-242.

50. Sherman K., Sissenwine M., Christensen V., Duda A., Hempel G., Ibe C., Levin S., Lluch-Belda D., Matishov G., McGlade J., O’Toole M., Seitzinger S., Serra R., Skjoldal H.-R., Tang Q., Thulin J., Vandeweerd V., Zwanenburg K.A. Global movement toward an ecosystem approach to management of marine resources. Mar. Ecol. Prog. Ser., 2005, vol. 300, pp. 275-279.

51. Order of the Ministry of Agriculture of the Russian Federation of October 27, 2017 No. 533 "On Approval of the Total Allowable Catch of Aquatic Biological Resources in the Inland Waters of the Russian Federation, the Territorial Sea of the Russian Federation, on the Continental Shelf of the Russian Federation and in the Exclusive Economic Zone of the Russian Federation, in the Azov and Caspian Seas for 2018. Available at: https://fishnews.ru/_img/docs/1132/prikaz_msh_-_533_ ot_27-10-17_ob_utv-_odu_morskoe_2018_god.p df (accessed: $10.0 \overline{1} \cdot 2020)$. (In Russ.). 